\title{
Pengaturan Tentang Ketentuan Sanksi Dalam Peraturan Daerah
}

\author{
Zairin Harahap
}

\section{Abstrak}

Most of bylaws consist of penal sanction whether fine or imprisonment. It is very rarely, the enforcement of bylaws proposes administrative sanction. Although most of bylaws relate to administrative matters. Are bylaws not allowed to impose other sanctions, such as administrative sanction?

\section{Pendahuluan}

Dalam Pasal 7 ayat (1) Undang-undang Nomor 10 Tahun 2004 tentang Pembentukan Peraturan Perundang-undangan (UUPPP) disebutkan, Jenis dan hierarki Peraturan Perundang-undangan adalah sebagai berikut:

a. Undang-Undang Dasar Negara Republik Indonesia Tahun 1945;

b. Undang-Undang/Peraturan Pemerintah Pengganti Undang-Undang;

c. Peraturan Pemerintah;

d. Peraturan Presiden;

e. Peraturan Daerah.

Dari ketentuan Pasal 7 ayat (1) UUPPP tersebut dapat diketahui bahwa, Peraturan Daerah (Perda) adalah salah satu jenis dan hierarki peraturan perundang-undangan. Sebagai konsekuensi logis dari adanya hirarki tersebut, maka materi muatan peraturan perundang-undangan yang lebih rendah tidak boleh bertentangan dengan materi muatan peraturan perundang-undangan yang lebih tinggi.
Di samping jenis peraturan perundangundangan tersebut, juga dikenal jenis peraturan perundang-undangan lainnya baik yang dikeluarkan oleh badan/lembaga/pejabat pemerintah pusat, seperti; Keputusan Presiden (Keppres), Peraturan Menteri (Permen), dan Keputusan Menteri (Kepmen), maupun peraturan perundang-undangan yang dikeluarkan oleh pemerintah daerah, seperti; Peraturan Gubernur, Peraturan Bupati, Peraturan Walikota, Keputusan Gubernur, Keputusan Bupati, dan Keputusan Walikota. Namun, apabila berpedoman kepada ketentuan Pasal 7 ayat (1) UUPPP tersebut; maka semua jenis peraturan perundangundangan yang tidak disebutkan dalam ketentuan Pasal 7 ayat (1) tersebut tidak termasuk dalam hierarki perundang-undangan.

Konsekuensi logis dari hierarki tersebut adalah Keppres, Permen, dan Kepmen tidak lagi termasuk jenis peraturan perundangundangan yang hierarkinya lebih tinggi dari Perda. Dengan demikian, Perda yang 
bertentangan dengan Keppres, Permen, dan Kepmen tidak dapat dibatalkan dengan alasan bahwa materi muatan dari Perda tersebut bertentangan dengan peraturan perundangundangan yang lebih tinggi.

Pada umumnya, sebagaimana peraturan perundang-undangan lainnya untuk memaksakan agar masyarakat memiliki ketaatan, maka pada peraturan perundangundangan tersebut dicantumkan sanksi. Namun, dalam kenyataannya, khususnya Perda pada umumnya hanya memuat sanksi pidana. Padahal, materi muatan yang diatur dalam setiap Perda boleh dikatakan hampir seluruhnya berkaitan dengan masalah administratif. Atas kenyataan itu, maka tulisan ini mencoba mengkaji apakah suatu Perda hanya dapat memuat sanksi yang berupa sanksi pidana saja.

\section{Proses Pembuatan Peraturan Daerah}

Rancangan Peraturan Daerah (Raperda) dapat berasal dari Dewan Perwakilan Rakyat Daerah (DPRD Provinsi/Kota/Kabupaten), Gubernur (Kepala Daerah Provinsi), Bupati (Kepala Daerah Kabupaten), atau Walikota (Kepala Daerah Kota) sesuai dengan kewenangannya. Namun, untuk dapat diberlakukan, maka Raperda tersebut harus mendapatkan persetujuan bersama antara DPRD Provinsi dan Gubernur untuk Raperda Provinsi, DPRD Kabupaten dan Bupati untuk Raperda Kabupaten, atau DPRD Kota dan Walikota untuk Raperda Kota. Oleh karena itu, Kepala Daerah dan DPRD dituntut untuk memahami materi muatan Perda, terutama pengaturan tentang ketentuan sanksi karena sangat terkait dengan efektivitas dari Perda itu sendiri.
Dalam Pasal 144 UUPD pada intinya disebutkan bahwa Rancangan Perda yang telah disetujui bersama disampaikan oleh pimpinan DPRD dalam jangka waktu 7 (tujuh) hari terhitung sejak tanggal ditetapkan sebagai Perda kepada Gubernur atau BupatiWalikota untuk ditetapkan sebagai Perda. Gubernur atau Bupati/Walikota dalam jangka waktu paling lama 30 (tiga puluh) hari sejak rancangan itu disetujui bersama harus telah menetapkan rancangan tersebut menjadi Perda. Apabila dalam jangka waktu tersebut tidak ditetapkan, maka rancangan Perda tersebut sah menjadi Perda.

Dengan demikian, paling lama 30 (tiga puluh) hari harus sudah ditetapkan menjadi Perda bukan sejak pimpinan DPRD menyampaikan rancangan Perda yang telah mendapatkan persetujuan bersama kepada Gubernur atau Bupati/Walikota. Tetapi, sejak rancangan Perda tersebut telah"mendapat persetujuan bersama. Namun, tidak ada konsekuensi hukum, apabila ternyata pimpinan DPRD menyampaikan rancangan Perda tersebut setelah 7 (tujuh) hari mendapatkan persetujuan bersama. Apakah dengan demikian, rancangan Perda tersebut batal demi hukum (van rechtswege nietig) atau dapat dibatalkan (vernietigbaar).

Perda yang telah ditetapkan oleh kepala daerah tersebut disampaikan kepada pemerintah paling lama 7 (tujuh) hari sejak ditetapkan.

Berdasarkan ketentuan Pasal 136 Undang-undang Nomor 32 Tahun 2004 tentang Pemerintahan Daerah, disebutkan bahwa Perda dibentuk dalam rangka penyelenggaraan otonomi daerah atau merupakan penjabaran lebih lanjut dari peraturan perundang-undangan yang lebih 
tinggi dengan memperhatikan ciri khas masingmasing daerah. Oleh karena itu, materi muatan Perda dilarang bertentangan dengan kepentingan umum dan/atau peraturan perundang-undangan yang lebih tinggi.

Perda yang bertentangan dengan kepentingan umum dan/atau peraturan yang lebih tinggi berdasarkan ketentuan Pasal 145 UUPD dapat dibatalkan oleh Pemerintah dengan Peraturan Presiden paling lama 60 (enam puluh) hari sejak diterimanya Perda tersebut. Paling lama 7 (tujuh) hari setelah pembatalan; kepala daerah harus memberhentikan pelaksanaan Perda dan selanjutnya bersama DPRD mencabut Perda tersebut. Terhadap pembatalan tersebut, Pemerintah Daerah yang bersangkutan dapat mengajukan keberatan kepada Mahkamah Agung:(MA).

Pembatalan Perda, karena bertentangan dengan peraturan perundang-undangan yang lebih tinggi dapat berpedoman kepada UUPPP. Namun, pembatalan Perda karena bertentangan dengan kepentingan umum belum ada peraturan yang dapat dijadikan pedoman. Sebagaimana diketahui sampai saat ini belum begitu jelas kriteria kepentingan umum. Apalagi dikaitkan dengan kapan suatu Perda dapat dikualifikasikan bertentangan dengan kepentingan umum ?

Sebelum dilakukan pembatalan oleh pemerintah, paling tidak Perda tersebut telah diberlakukan sekitar 2 (dua) bulan. Oleh karena itu, perlu dipikirkan dampak dari pembatalan tersebut, khususnya yang berkaitan dengan kepentingan masyarakat ketika Perda tersebut diberlakukan. Beberapa contoh yang dapat dikemukakan di sini adalah mereka yang dikenakan hukuman sebagai akibat melanggar Perda tersebut dan mereka yang mendapatkan jenis perizinan tertentu pada waktu berlakunya Perda tersebut. Apakah dengan pembatalan tersebut, segala sesuatu yang dilakukan oleh pemerintah daerah yang berkaitan dengan pelaksanaan Perda tersebut batal demi hukum (van rechtswege nietig) atau dapat dibatalkan (vernietigbaar)?

\section{Dasar Hukum Pengaturan Sanksi Dalam Peraturan Daerah}

Salah satu materi muatan yang diatur dalam peraturan perundang-undangan tak terkecuali Peraturan Daerah (Perda) adalah ketentuan sanksi. Dewasa ini, paling tidak ada 2 (dua) peraturan perundang-undangan yang dapat dijadikan acuan tentang jenis sanksi yang dapat dimuat dalam Perda, yaitu; Undangundang Nomor 10 Tahun 2004 tentang Pembentukan Peraturan Perundang-undangan (UUPPP) dan Undang-undang Nomor 32 Tahun 2004 tentang Pemerintahan Daerah (UUPD) sebagaimana yang dikutipkan di bawah ini:

1. Pasal 14 Undang-undang Nomor 10 Tahun 2004 tentang Pembentukan Peraturan Perundang-undangan menyebutkan:

(UUPPP)

"Materi muatan mengenai ketentuan pidana hanya dapat dimuat dalam Undang-undang dan Peraturan Daerah".

2. Pasal 143 Undang-undang Nomor 32 Tahun 2004 tentang Pemerintahan Daerah (UUPD) menyebutkan:

(1) Perda dapat memuat ketentuan tentang pembebanan biaya paksaan penegakan hukum, seluruhnya atau sebagian kepada pelanggar sesuai dengan peraturan perundangan;

(2) Perda dapat memuat ancaman 
pidana kurungan paling lama 6 (enam) bulan atau denda paling banyak Rp 50.000 .000 ,- (lima puluh juta rupiah);

(3) Perda dapat memuat ancaman pidana atau denda selain dimaksud pada ayat (2), sesuai dengan yang diatur dalam peraturan perundangan lainnya.

Substansi rumusan ketentuan Pasal 143 UUPD tersebut tidak jauh berbeda dengan rumusan ketentuan Pasal 71 Undang-undang Nomor 22 Tahun 1999 tentang Pemerintahan Daerah, yang menyebutkan:

(1) Peraturan Daerah dapat memuat ketentuan tentang pembebanan biaya paksaan penegakan hukum, seluruhnya atau sebagian kepada pelanggar;

(2) Peraturan Daerah dapat memuat pidana kurungan paling lama enam bulan atau denda sebanyak-banyaknya $R p$ $5.000 .000,00$ (lima juta rupiah) dengan atau tidak merampas barang tertentu untuk daerah, kecuali jika ditentukan lain dalam peraturan perundang-undangan.

\section{Jenis-Jenis Sanksi (Hukuman) dalam Peraturan Daerah}

Dari ketentuan Pasal 14 UUPPP dan Pasal 143 UUPD sebagaimana dikemukakan di atas, dapat ditarik kesimpulan sebagai berikut:

1. Peraturan Daerah dapat memuat sanksi pidana;

2. Kata "dapat" sebagaimana yang disebutkan pada Pasal 143 tersebut bersifat diskresi, sehingga memiliki makna bahwa sanksi pidana dapat dicantumkan pada suatu peraturan daerah dan juga dapat tidak mencantumkan atau memuat sanksi pidana. Apabila tidak memuat sanksi pidana tidak berarti tidak sesuai dengan ketentuan Pasal 143;

3. Dewasa ini banyak para ahli hukum pidana seperti Prof. Muladi dan Prof. Lobby Luqman berpandangan bahwa sanksi pidana dicantumkan sebagai ultimum remedium bukan primum remidium. Artinya; sanksi pidana patut dicantumkan, apabila penegakan hukum administrasi diasumsikan tidak dapat dilaksanakan sebagaimana mestinya, sehingga memerlukan ancaman yang lebih keras lagi; ${ }^{1}$

4. Sanksi pidana yang dapat dimuat dalam suatu Perda, apabila bukan pengaturan tindak lanjut dari suatu peraturan perundang-undangan yang lebih tinggi, maka harus tunduk pada ketentuan Pasal 143 ayat (2), yakni; sanksi pidana yang dapat diancamkan adalah pidana kurungan yang tidak boleh lebih dari 6 (enam) bulan atau denda paling banyak Rp 50.000.000,- (lima puluh juta rupiah);

5. Sanksi pidana yang dimuat dalam suatu Perda dapat saja melebihi sanksi pidana yang ditentukan dalam Pasal 143 ayat (2) UUPD, sepanjang Perda tersebut dibuat sebagai pelaksanaan peraturan perundang-undangan yang lebih tinggi. Tetapi, juga perlu diperhatikan bahwa peraturan perundang-undangan yang

1 Zafrullah Salim, Ulasan terhadap Beberapa Teknik Penyusunan Peraturan Perundang-undangan, bahan untuk acara implementasi UU 10/2004, yang diselenggarakan oleh Ditjen Peraturan Perundang-undangan bekerja sama dengan Kanwil Dep. Hukum dan HAM DIY, tanggal 20 Oktober 2005, him 4-5. 
menjadi dasar hukum pembentukan Perda itu memang memuat ketentuan sanksi pidana seperti yang dimuat dalam Perda tersebut.

6. Kata "atau" diantara pidana kurungan dan denda pada Pasal 143 ayat (2) di atas, menunjukkan bahwa sanksi pidana tersebut bersifat alternatif, sehingga kepada pelaku pelanggaran diberikan kebebasan untuk memilih jenis sanksinya. Dengan kata lain, apabila si pelaku memilih pidana kurungan, maka kepadanya tidak dapat lagi dikenakan sanksi pidana denda, begitu sebaliknya;

7. Berdasarkan ketentuan Pasal 143 ayat (1), kepada si pelaku pelanggaran Perda, di samping dapat dikenakan sanksi pidana (pidana kurungan atau pidana denda) dapat juga dikenakan sanksi yang berupa pembebanan biaya paksaan. Sanksi yang berupa pembebanan biaya paksaan atau yang juga dikenal dengan istilah dwangsom adalah merupakan salah satu jenis sanksi administrasi;"2 Menurut Hadjon, jenis-jenis sanksi administrasi adalah paksaan nyata (bestuursdwang), uang paksa (dwangsom), denda administrasi, pencabutan KTUN yang menguntungkan (misalnya; izin), uang jaminan, dan bentuk-bentuk lain/khusus, seperti; peringatan dan pengumuman. ${ }^{3}$

8. Pelanggaran terhadap Perda juga sangat potensial dilakukan oleh aparat, pegawai, atau pejabat pemerintahan. Oleh karena itu, jenis sanksi administrasi sebagaimana yang disebutkan dalam Pasal 6 Peraturan Pemerintah Nomor 30 Tahun 1980 tentang Disiplin Pegawai Negeri Sipil menjadi sangat relevan untuk dipergunakan. Pasal 6 PP 30/1980 menyebutkan jenis sanksi administrasi yang dapat dijatuhkan kepada PNS yang melakukan pelanggaran disiplin adalah hukuman disiplin ringan (yang dapat berupa tegoran lisan, tegoran tertulis, dan pernyataan tidak puas secara tertulis), hukuman disiplin sedang (yang dapat berupa penundaan kenaikan gaji berkala untuk paling lama 1 (satu) tahun, penurunan gaji sebesar satu kali kenaikan gaji berkala untuk paling lama 1 (satu) tahun, dan penundaan kenaikan pangkat untuk paling lama 1 (satu) tahun), dan hukuman disiplin berat (yang dapat berupa penurunan pangkat pada pangkat yang setingkat lebih rendah untuk paling lama 1 (satu) tahun, pembebasan dari jabatan, pemberhentian dengan hormat tidak atas permintaan sendiri sebagai PNS, dan pemberhentian tidak dengan hormat sebagai PNS);

9. Di samping itu, dalam kaitannya dengan penegakan hukum lingkungan, mengingat banyak materi muatan dari Perda juga berkaitan dengan pengaturan lingkungan hidup, maka jenis sanksi administrasi dalam kaitannya dengan penegakan hukum lingkungan, yaitu; paksaan pemerintahan atau tindakan paksa (bestuursdwang = executive coercion), uang paksa (publiek-rechtelijke

${ }^{2}$ Philipus M. Hadjon, Penegakan Hukum Administrasi dalam Pengelolaan Lingkungan Hidup, dalam B. Arief Sidharta, dkk (Editor), Butir-butir Gagasan tentang Penyelenggaraan Hukum dan Pemerintahan yang Layak, Penerbit PT. Citra Aditya Bakti, Bandung, 1996, hlm 339-341. Lihatjuga Philipus M. Hadjon, Pengantar Hukum Administrasi Indonesia, Gadjah Mada University Press, Yogyakarta, 1993, hIm 241.

${ }^{3} \mathrm{lbid}$. 
dwangsom $=$ coercive sum), penutupan tempat usaha (sluiting van een inrichting), penghentian kegiatan mesin perusahaan (buitengebruikstelling van een toestel), pencabutan izin melalui proses, teguran, paksaan pemerintahan, penutupan, dan uang paksa. ${ }^{4}$

10. Dengan demikian, Perda di samping dapat memuat sanksi pidana juga dapat memuat sanksi administrasi;

\section{Materi Muatan Peraturan Daerah yang Harus Diikuti dengan Ancaman Sanksi}

Ketentuan sanksi dalam suatu peraturan perundang-undangan terkait dengan isi dan sifat kaidah hukum. Ditinjau dari isinya, kaidah hukum (norma hukum) dapat dibagi menjadi: 1. kaidah hukum yang berisi suruhan (gebod);

2. kaidah hukum yang berisi larangan (verbod);

3. kaidah hukum yang berisi kebolehan (mogen). ${ }^{5}$

Kaidah suruhan adalah suatu perintah untuk melaksanakan sesuatu yang biasanya dinyatakan dengan kata "wajib" atau "harus". Kaidah larangan juga merupakan perintah untuk tidak melakukan sesuatu, yang sering dirumuskan dengan kata "dilarang", "tidak boleh", atau "tidak dapat".

Ditinjau dari sifatnya, kaidah hukum dapat dibedakan antara kaidah hukum yang bersifat imperatif dan kaidah hukum yang bersifat fakultatif. Kaidah hukum yang berisikan suruhan dan larangan adalah kaidah hukum yang bersifat imperatif, sedangkan kaidah hukum yang berisikan kebolehan adalah kaidah hukum yang bersifat fakuitatif. ${ }^{6}$

Perbedaan antara hukum imperatif dengan hukum fakultatif, didasarkan pada sifatnya.Artinya, hukum imperatif bersifat memaksa, sedangkan hukum fakultatif dibolehkan memilih. ${ }^{7}$ Kaidah hukum yang bersifat imperatif ( $d$ wingenrecht) atau nomatiefrecht adalah aturan hukum yang tidak dapat dikesampingkan oleh pihak-pihak, baik melalui suatu perbuatan tertentu atau melalui suatu perjanjian. ${ }^{8}$

Ciri hukum positif menurut Hans Kelsen adalah a coercive order atau suatu tatanan yang memaksa". Paksaaan merupakan salah satu bentuk sanksi yaitu perampasan atau perenggutan secara paksa di luar kemauan yang terkena terhadap segala sesuatu yang dimiliki seperti nyawa, kebebasan, atau harta benda. Meskipun demikian, Kelsen mengatakan bahwa sanksi tidak hanya berupa hukuman (punishment), tetapi dapat juga berupa ganjaran (reward). ${ }^{9}$ A. Hamid S. Attamimi, juga mengatakan bahwa sanksi (dalam hal ini sanksi pidana atau sanksi

${ }^{4}$ Siti Sundari Rangkuti, Hukum Lingkungan dan Kebijaksanaan Lingkungan Nasional, Edisi Kedua, Airlangga University Press, Surabaya, 2000, hlm 211.

${ }_{5}^{5}$ Purnadi Purbacaraka dan Soerjono Soekanto, Perihal Kaidah Hukum, Penerbit PT. CitraAditya Bakti, Bandung, 1993, him 34.

${ }^{6} \mathrm{lbid}$, him 36 .

' Soerjono Soekanto dan Pumadi Purbacaraka, Aneka Cara Pembedaan Hukum, Penerbit PT. Citra Aditya Bakti, Bandung, 1994, him 22.

${ }^{8}$ Bagir Manan, Hukum Positif Indonesia (Suatu Kajian Teoritik), Penerbit Fakultas Hukum Ull Press, Yogyakarta, 2004, him 8.

${ }^{9} \mathrm{lbid}, \mathrm{hlm} 6-7$. 
pemaksa lainnya) adalah merupakan salah satu ciri yang membedakan norma hukum dengan norma lainnya (adat, agama, dan moral). ${ }^{10}$ Perbedaan yang menonjol antara kaidah hukum dengan kaidah sosial lainnya ialah sanksinya. Sanksi terhadap pelanggaran kaidah hukum dapat dipaksakan, dapat dilaksanakan di luar kemauan yang bersangkutan."

Perlunya pencantuman sanksi dalam suatu peraturan perundang-undangan secara lebih tegas dikemukakan Pospisil. Menurut Pospisil ada 4 (empat) atribut hukum, yakni: ${ }^{12}$ 1. adanya wewenang;

2. adanya tujuan untuk memperlakukan hukum secara universal;

3. adanya hak dan kewajiban (obligatio);

4. adanya sanksi.

Atribut sanksi dimaksudkan agar hukum "bergigi"; "gigi" itulah yang disebut dengan sanksi. Kaidah hukum yang berupa suruhan (kewajiban) atau larangan akan menjadi pepesan kosong atau garansi kosong, dan cenderung tidak dipatuhi sama sekali apabila tidak dilekati dengan sanksi. Sebagai salah satu contoh adalah ketentuan Pasal 59 ayat (3) UUPD yang menyebutkan:

"Partai politik atau gabungan partai politik wajib membuka kesempatan yang seluasluasnya bagi calon perseorangan yang memenuhi syarat sebagaimana dimaksud dalam Pasal 58 dan selanjutnya memproses bakal calon dimaksud melalui mekanisme yang demokratis dan transparan".

Namun, kata wajib pada pasal tersebut menjadi macan ompong, karena tidak diikuti dengan adanya ketentuan ancaman sanksi. Dengan demikian, apabila ketentuan itu tidak dilaksanakan atau tidak diikuti, maka partai politik tersebut tidak dapat dikenakan sanksi. Penjaringan bakal calon kepala daerah yang dilakukan oleh partai politik telah menunjukkan pelanggaran terhadap ketentuan pasal tersebut. Hampir dapat dipastikan seluruh bakal calon kepala daerah yang diajukan oleh partai politik tidak saja kurang memberikan kesempatan kepada calon perorangan (non-partisan). Tetapi, juga penentuan bakal calon tidak berlangsung secara demokratis dan transparan. Bahkan, seorang bakal calon Bupati di kabupaten Sleman yang telah memenangkan konvensi yang dilakukan oleh gabungan beberapa partai politik tidak diajukan sebagai bakal calon, tetapi malah mengajukan calon yang tidak menang.

Oleh karena itu, sanksi pada satu pihak merupakan kriteria yang mutlak dari hukum dan pada pihak lain sanksi tidak selamanya harus berbentuk sanksi fisik. ${ }^{13}$ Bahkan, sebenarnya atribut sanksi tidak perlu hanya dibatasi pada sanksi yang negatif saja (baik fisik maupun psikologis). Dalam hukum juga ditemukan sanksi-sanksi positif yang merupakan imbalan yang diberikan kepada mereka yang dapat dijadikan contoh dalam kualitas ketaatan hukum. Hal itu sesuai dengan

${ }^{10}$ Maria Farida Indrati Soeprapto, IImu Perundang-undangan: Dasar-dasar dan Pembentukannya, Penerbit Kanisius, Yogyakarta, 1998, hlm 10-11:

"Sudikno Mertokusumo, Mengenal Hukum Suatu Pengantar, Penerbit Liberty, Yogyakarta, 1999, hlm 18.

${ }^{12}$ Soerjono Soekanto, Antropologi Hukum: Materi Pengembangan Imu Hukum Adat, Penerbit CV. Rajawali, Jakarta, 1984, hlm 151- 157.

${ }^{13}$ Hilman Hadikusuma, PengantarAntropologi Hukum, PenerbitPT. CitraAditya Bakti, Bandung, 1992, him 116. 
arti sanksi, yakni rangsangan untuk berbuat atau tidak berbuat. Di dalam hal sanksi negatif, maka sebaiknya diterapkan sistematik, sebagai berikut: ${ }^{14}$

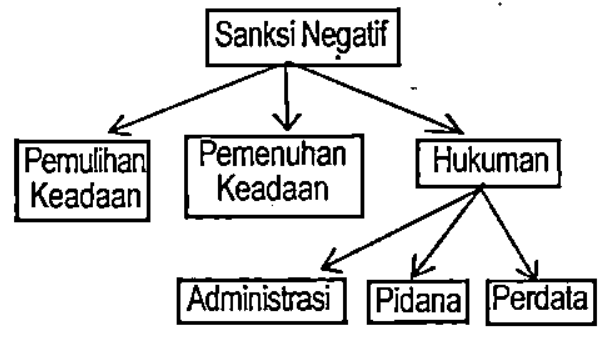

Apabila mengacu kepada Pasal 25 ayat (1) Undang-undang Pengelolaan Lingkungan Hidup (UUPLH), maka sanksi yang berupa pemulihan keadaan dan pemenuhan keadaan tersebut merupakan bentuk-bentuk dari sanksi administrasi yang berupa paksaan pemerintahan (bestuursdwang). Pasal 25 ayat (1) UUPLH menyebutkan:

"Gubernur/Kepala Daerah Tingkat I berwenang melakukan paksaan pemerintahan terhadap penanggung jawab usaha dan/atau kegiatan untuk mencegah dan mengakhiri terjadinya pelanggaran, serta menanggulangi akibat yang ditimbulkan oleh suatu pelanggaran, melakukan tindakan penyelamatan, penanggulangan, dan/atau pemulihan atas beban biaya penanggung jawab usaha dan/ atau kegiatan, kecuali ditentukan lain berdasarkan Undang-undang".

\section{Kumulasi Sanksi}

Berangkat dari ketentuan Pasal 14 UUPD dan Pasal 143 UUPD sebagaimana yang telah

${ }^{14}$ Soerjono Soekanto, Op. Cit, hlm 174.

${ }^{15}$ Phlipus M. Hadjon, Op. Cit, hlm 342-345. dikemukakan di atas, maka Perda dapat saja memuat sanksi yang bersifat kumulatif. Artinya, materi muatan Perda dapat memuat sanksi administrasi, sanksi perdata, dan sanksi pidana sekaligus, serta ketiga jenis sanksi tersebut dapat diterapkan sekaligus terhadap pelaku pelanggaran Perda.

Sanksi administrasi dapat diterapkan bersama-sama baik eksternal mapun internal. Kumulasi sanksi dibedakan atas; kumulasi eksternal dan kumulasi internal. Kumulasi ekstemal adalah sanksi administrasi diterapkan bersama-sama sanksi lain, seperti sanksi pidana maupun sanksi perdata. Kumulasi internal adalah dua atau lebih sanksi adminitrasi dapat diterapkan secara bersama-sama. ${ }^{15}$ Kumulasi sanksi pada dasarnya berkaitan dengan keseimbangan sanksi. Artinya, sanksi harus seimbang dengan berat ringannya pelanggaran.

Penjatuhan sanksi administrasi dilakukan oleh pejabat yang mendapatkan wewenang atribusi ataupun delegasi sebagaimana yang disebutkan dalam Perda tersebut. Penjatuhan sanksi administrasi dapat dilakukan secara langsung oleh pejabat yang bersangkutan tanpa harus melalui putusan pengadilan. Orang atau badan hukum perdata yang merasa dirugikan akibat penjatuhan sanksi tersebut dapat mengajukan gugatan ke Peradilan Tata Usaha Negara (PTUN). PTUN akan menilai (rechtmatige toetsing) apakah putusan pejabat tersebut tentang penjatuhan sanksi administrasi itu sah menurut hukum (rechtmatigeheid) atau tidak.

Sementara itu, penjatuhan sanksi pidana kepada pelaku pelanggaran Perda tidak dapat dijatuhkan secara langsung. Artinya, orang 
yang.melakukan pelanggaran Perda tersebut langsung dimasukkan ke penjara atau dikenakan denda begitu diketahui melakukan pelanggaran. Penjatuhan sanksi pidana harus dilakukan melalui proses peradilan. Sepanjang belum ada putusan hakim yang telah mempunyai kekuatan hukum yang bersifat tetap, maka orang yang melakukan pelanggaran terhadap Perda tersebut harus dianggap belum bersalah. Hal itu sejalan dengan asas praduga tak bersalah (presumption of innosence). Dengan demikian, penjatuhan sanksi pidana dalam penegakan hukum Perda di atas kertas menjadi sangat memakan waktu dari mulai melakukan proses penyelidikan, pembuatan berita acara, sampai beracara di pengadilan. Padahal, begitu banyak Perda yang harus dilaksanakan dan secara otomatis juga harus ditegakkan (law enforcement).

Namun, dalam kenyataannya, sangat banyak Perda yang hanya memuat sanksi pidana saja yang berupa pidana kurungan yang dialternatifkan dengan pidana denda, persis sebagaimana yang diatur dalam UUPD. Padahal, sebagaimana yang telah dikemukakan di atas, tidak ada larangan materi muatan Perda memuat ketentuan sanksi selain sanksi pidana. Larangan yang ada secara eksplisit adalah bagi jenis peraturan perundang-undangan selain UU dan Perda dilarang atau tidak boleh memuat sanksi pidana.

Kesalahpahaman ini sedikit banyak telah membuat penegakan hukum Perda cenderung sulit dan tidak efektif. Salah satu penyebab utamanya adalah materi muatan yang diatur dalam Perda pada umumnya bersifat administratif, sedangkan ketentuan sanksi yang diatur adalah pidana. Sebagaimana diketahui, penjatuhan sanksi pidana sasarannya ditujukan kepada pelakunya, sedangkan penjatuhan sanksi administrasi sasarannya ditujukan kepada perbuatannya. Dengan kata lain, penjatuhan sanksi administrasi adalah ditujukan untuk mengakhiri perbuatan melawan hukum, sedangkan penjatuhan sanksi pidana adalah ditujukan untuk menghukum si pelaku dengan memenjarakannya dan/atau membayar sejumlah denda. Dalam kasus pencemaran dan/atau perusakan lingkungan, dengan dipenjaranya atau didendanya si pelaku berarti tidak menyelesaikan masalah, karena sumber pencemarannya tidak tersentuh. Pencemaran dan/atau perusakan lingkungan hidup terus berlanjut dan sangat potensial semakin meluas, karena pabrik sebagai sumber pencemaran dan/atau perusakan lingkungan tidak dijatuhkan sanksi. Berbeda halnya dengan sanksi administrasi, maka dapat dijatuhkan sanksi administrasi seperti; penutupan tempat usaha atau pencabutan izin, sehingga pabrik tidak dapat beroperasi lagi. Dengan tidak beroperasinya pabrik tersebut paling tidak dapat dicegah semakin meluasnya dampak pencemaran dan/atau perusakan lingkungan. Pabrik baru dapat beroperasi lagi setelah melakukan pemulihan lingkungan dan membangun instalasi pengolah limbah dan sebagainya.

Sedangkan pengaturan sanksi perdata dalam Perda lebih merupakan memberikan peluang kepada masyarakat untuk menuntut ganti kerugian kepada pelaku pelanggaran Perda yang menimbulkan kerugian kepadanya. Oleh karena itu, sudah seharusnya ketentuan sanksi yang diatur dalam Perda tidak hanya mengenai sanksi pidana. Tetapi, juga memuat sanksi administrasi dan sanksi perdata. Persoalan mengenai, apakah penerapan sanksi pidana ditempatkan sebagai uttimum remedium adalah 
persoalan lain. Namun, paling tidak, dengan juga dicantumkannya sanksi pidana dapat menjadi dasar hukum bagi aparat penegak hukum untuk menjatuhkan sanksi yang lebih keras ketika si pelaku pelanggaran Perda tidak dapat diterapi dengan sanksi administrasi.

\section{Tempat Ketentuan Sanksi Pada Peraturan Daerah}

Dalam Lampiran UUPPP disebutkan isi dari Batang Tubuh suatu peraturan perundang-undangan adalah:

1. Ketentuan Umum;

2. Materi Pokok yang diatur;

3. Ketentuan Pidana (jika diperlukan);

4. Ketentuan Peralihan (jika diperlukan);

5. Ketentuan Penutup.

Dengan demikian, ketentuan sanksi yang menyangkut Ketentuan Pidana ditempatkan setelah Materi Pokok. Pada umumnya dalam suatu peraturan perundang-undangan, penempatan dan pengaturan Ketentuan Pidana dipisahkan dengan Ketentuan Sanksi yang lainnya (sanksi administrasi dan/atau sanksi perdata). Apabila peraturan perundangundangan tersebut juga memuat sanksi administrasi dan/atau sanksi perdata dapat ditempatkan dan diatur pada Materi Pokok. ${ }^{16}$

Kehadiran ketentuan pidana dalam materi muatan suatu peraturan perundang-undangan berdasarkan Lampiran UUPPP tersebut di atas disebutkan jika diperlukan. Dengan demikian, sesungguhnya suatu peraturan perundanganundangan, tidak terkecuali Perda dapat saja tidak mencantumkan sanksi pidana di dalamnya. Tidak dicantumkannya sanksi pidana atau suatu Perda yang tidak memuat sanksi pidana tidak berarti Perda tersebut bertentangan dengan UUPPP dan UUPD. Sebagaimana yang telah dikemukakan di atas bahwa ketentuan Pasal 143 UUPD menyebutkan kata dapat. Dengan demikian, materi muatan Perda dapat memuat sanksi pidana, tetapi juga dapat tidak memuat sanksi pidana.

Apabila ketentuan itu ditafsirkan lebih luas lagi, maka suatu peraturan perundangundangan tidak terkecuali Perda dapat tidak mencantumkan sanksi hukum sama sekali, baik sanksi pidana, sanksi administrasi, maupun sanksi perdata. Namun demikian, perlu dipahami bahwa pencantuman atau tidak mencantumkan sanksi dalam suatu peraturan perundang-undangan hendaknya jangan didasarkan kepada selera kekuasaan. Begitu juga, apakah peraturan perundang-undangan tersebut hanya memuat sanksi administrasi saja atau sanksi pidana saja, atau perdata saja, atau semua jenis sanksi harus dicantumkan juga hendaknya jangan didasarkan kepada selera kekuasaan. Pencantuman sanksi dan jenis sanksi apa saja yang tepat dalam rangka menegakkan peraturan perundang-undangan tersebut haruslah berdasarkan kajian dan pertimbangan ilmiah. Pada dasamya, kehadiran ketentuan sanksi dalam suatu peraturan perundang-undangan adalah dalam rangka agar peraturan perundang-undangan tersebut dipatuhi oleh masyarakat.

Oleh karena itu, kata jika diperlukan sebagaimana yang disebutkan dalam Lampiran UUPPP tersebut haruslah ditafsirkan dalam rangka mendorong agar peraturan perundangundangan tersebut dipatuhi oleh masyarakat.

${ }^{16}$ Lihat antara lain Undang-undang Nomor 23 Tahun 1997 tentang Pengelolaan Lingkungan Hidup (UUPLH). 
Artinya, kalau tanpa adanya ketentuan sanksi. pidana dan/atau sanksi-sanksi lainnya dapat dipastikan peraturan perundang-undangan tersebut dipatuhi, maka kehadiran ketentuan sanksi menjadi tidak diperlukan. Namun, sebaliknya kalau hal itu tidak dapat dipastikan untuk dipatuhi tanpa adanya ketentuan sanksi, maka kehadiran ketentuan sanksi menjadi tidak bisa tidak atau menjadi mutlak adanya.

\section{Simpulan}

Berdasarkan ketentuan Pasal 143 UUPD sangat jelas bahwa tidak ada larangan bahwa suatu Perda tidak boleh mencantumkan sanksi administrasi. Bahkan, ketentuan ayat (1) yang mengatakan Perda dapat memuat ketentuan tentang pembebanan biaya paksaan penegakan hukum adalah merupakan salah satu jenis sanksi administrasi. Di samping itu, pencantuman sanksi pidana yang berupa pidana kurungan atau denda sebagaimana dimaksud pada ayat (2) bersifat diskresi.

Ketentuan sanksi pidana baik yang berupa pidana kurungan maupun pidana denda tidak selamanya harus sama dengan ketentuan Pasal 143 ayat (2) UUPD. Tetapi, bisa saja lebih ringan, karena rumusan yang di anut adalah hukuman maksimal atau paling banyak/tinggi. Sebaliknya juga bisa lebih berat, sepanjang Perda tersebut dibentuk dalam rangka melaksanakan peraturan perundangundangan yang lebih tinggi dimana peraturan perundang-undangan yang memberikan delegasi itu mengatur ketentuan seperti itu.

Dengan demikian, Perda sesungguhnya boleh tidak mencantumkan sanksi pidana. Apabila suatu Perda tetap mencantumkan sanksi pidana, maka sebaiknya penerapan sanksi pidana tersebut bersifat ultimum remedium.

\section{Daftar Pustaka}

Bagir Manan, Hukum Positif Indonesia (Suatu Kajian Teoritik), Penerbit Fakultas Hukum UII Press, Yogyakarta, 2004.

B. Arief Sidharta, dkk (Editor), Butir-butir Gagasan tentang Penyelenggaraan Hukum dan Pemerintahan yang Layak, Penerbit PT. Citra Aditya Bakti, Bandung, 1996.

Hilman Hadikusuma, Pengantar Antropologi Hukum, Penerbit PT. Citra Aditya Bakti, Bandung, 1992.

Maria Farida Indrati Soeprapto, IImu Perundang-undangan: Dasar-dasar dan Pembentukannya, Penerbit Kanisius, Yogyakarta, 1998.

Philipus M. Hadjon, Pengantar Hukum Administrasi Indonesia, Gadjah Mada University Press, Yogyakarta, 1993.

Purnadi Purbacaraka dan Soerjono Soekanto, Perihal Kaidah Hukum, Penerbit PT. Citra Aditya Bakti, Bandung, 1993.

Soerjono Soekanto, Antropologi Hukum: Materi

Pengembangan IImu Hukum Adat, Penerbit CV. Rajawali, Jakarta, 1984.

Soerjono Soekanto dan Purnadi Purbacaraka, Aneka Cara Pembedaan Hukum, Penerbit PT. Citra Aditya Bakti, Bandung, 1994.

Siti Sundari Rangkuti, Hukum Lingkungan dan Kebijaksanaan Lingkungan Nasional, Edisi Kedua, Airlangga University Press, Surabaya, 2000.

Sudikno Mertokusumo, Mengenal Hukum Suatu Pengantar, Penerbit Liberty, Yogyakarta, 1999.

Zafrullah Salim, Ulasan Terhadap Beberapa

Teknik Penyusunan Peraturan

Perundang-undangan, bahan untuk acara implementasi UU 10/2004, yang 
Harahap. Pengaturan Tentang Ketentuan Sanksi ...

diselenggarakan oleh Ditjen Peraturan

Perundang-undangan bekerja sama dengan Kanwil Dep. Hukum dan HAM DIY, tanggal 20 Oktober 2005. 